\title{
Delaney clause knocked out by surprise compromise act
}

\author{
Russ Hoyle
}

After a bruising, three-year battle between the White House and its Congressional opponents, in August President Clinton signed historic legislation that promises to revolutionize the way the US federal government regulates pesticides. The bill closes a chapter on pesticide safety in agriculture that began with the publication of Rachel Carson's Silent Spring. It also vindicates a Clinton strategy of environmental consensusbuilding. Perhaps most importantly, the new legislation, called the Food Quality Protection Act, will significantly enhance the new multibillion-dollar agricultural biotechnology biopesticide industry that is already marketing naturally occurring and genetically engineered products to replace chemical pesticides.

The new law removes one of the last and most formidable regulatory obstacles to the production of innovative, nonchemical pesticides, and herbicides: the Delaney clause of the amended 1938 Food, Drug, and Cosmetics Act.

\section{Although the Clinton administration has taken a low profile on the passage of the bill, it represents a major political victory.}

The Delaney clause, passed by Congress in 1958 to protect consumers from cancer-causing pesticides such as DDT, banned any trace of known animal carcinogens in processed foods, and has long been considered a scientific anachronism in an age when pesticidal residues can be measured down to parts per trillion-levels so miniscule that they are exceeded by naturally occurring toxins in unregulated foods.

Although the Delaney clause is still held sacrosanct by some environmentalists as a paradigm of zero-risk environmental regulation, its demise hardly represents the unraveling of environmental protections against toxic or carcinogenic pesticides. Drafters of the new legislation, working toward an across-the-board strategy to assure negligible risk to consumers, called for a reasonable certainty of protection against pesticide contamination for all foods, including foods for infants and children. That threshold was set at one part per million for known carcinogens or toxins--a standard that is, if anything, more rigorous than many current federal regulations for whole foods.

The bill also calls for a review of regulated chemical and other pesticides within 10 years, all of which would have to meet the new standard. This amounts to a significant compromise on the part of environmentalists who serve on the president's Environmental Working Group-a loose organization of industry officials and representatives of environmental groups that has been involved in behind-thescenes negotiations. Three years ago, when Clinton-administration officials first proposed a similar review to phase out chemical pesticides, the timetable given was seven years.

In the Senate, Richard Lugar (R-Ind.) and Patrick Leahy (D-Vt.), leaders of the Senate agricultural committee, pushed the bill through the Senate at the end of July. President Clinton signed the legislation on August 3.

Although the Clinton administration has taken a low profile on the passage of the bill, it represents a major political victory for the White House and for Carol Browner, the administrator of the Environmental Protection Agency.

Two years ago the administration's ambitious pesticide reform legislation was stalled and all but dead, even before House Speaker Newt Gingrich and his majority of Republican bombthrowers swept into office in November 1994. The previous summer, a toxic combination of administration ineptness and intense lobbying pressure by agricultural and chemical companies chewed up the highly complex legislative package that Clinton staffers cobbled together. It was never reported out of the House agriculture committee, thanks, in part, to the storm over health care and the president's crime bill.

The Clinton White House, however, had an ace that it was not in a position to play until this year, when reality caught up with the Republican revolution and the 104th Congress: The Delaney clause was still in effect, and a San Francisco US federal district court had ordered the EPA to enforce it, scientific flaws notwithstanding. That meant that some 60 chemical pesticides on the market would have to be banned outright, rather than undergo a lengthy review process as new products were developed. Clinton officials, driven by the court order, contrived to set the reform process in motion by proposing a gradual phase-out of potentially carcinogenic pesticide and a new negligible-risk standard to replace the Delaney clause.

Two factors broke the legislative logjam. First, under pressure from the Republican Congress, the EPA moved swiftly in concert with industry in 1995 to commercialize the first transgenic pesticides. That in turn sparked a shakeout in the agricultural biotechnology industry, as companies great and small jockeyed to position new pesticide products in the marketplace-at once giving big companies like Monsanto, Ciba Geigy, and Dow Chemical more incentive to get behind innovative, nonchemical products and less incentive to fight reform legislation.

Second, the administration's artful compromise between industry and moderate environmentalists neatly exploited the political backlash against the antienvironmental rhetoric of the Republican revolution in Congress. The gathering election year consensus, it seems, is that the United States is ready for sound environmental policies from the federal government that benefit industry.

The biotechnology industry owes the Clinton administration a debt of gratitude - and support-for securing the passage of this pesticide reform bill, and for sticking to its guns under adverse political circumstances.

\section{Salquist resigns}

In a not-so-surprising turnabout of another sort, Roger Salquist, the president and chief executive officer of Calgene (Davis, CA), announced his resignation after 12 years at the helm of the troubled biotechnology company, best known for its commercialization of the genetically engineered Flavr-Savr tomato. In a complex deal that was finally consummated earlier this year, Monsanto acquired a $49.9 \%$ stake in Calgene for $\$ 40$ million, giving the newly minted corporate subsidiary a much needed infusion of cash.

The outspoken Salquist, cut the lucrative deal with Monsanto that saved his companyand led to his undoing. Despite his insistence in recent months that his job at the head of $\mathrm{Cal}$ gene was not in jeopardy (see Nature Biotechnology 14:548, May 1996), Salquist's resignation came after Monsanto injected another $\$ 50$ million into the biotech company, bringing its total ownership to $54.6 \%$ of Calgene's stock and five positions on its nine-member board. Calgene's stock, which had been languishing for most of 1995 and recently sold for less than $\$ 5$ a share, jumped to $\$ 6.1875$ per share at the news that Monsanto had, as expected, taken a majority position in Calgene and that Salquist had stepped down.

For the moment, at least, Salquist will be replaced by Lloyd Kunimoto, a Calgene vice president for strategic development. Salquist will retain a position on Calgene's board and serve as a consultant to the company. 